\title{
Analysis of Ecofeminism and Its Influence on Lessing's The Cleft
}

\author{
Yuzhuo Cui \\ Changchun University of Finance and Economics Changchun, China \\ 1493116216@qq.com
}

Keywords: Ecofeminism; exclusion; Women; Nature; Harmony

\begin{abstract}
Doris Lessing (1919-2013), who is Britain's outstanding and fertile woman novelist, won the Nobel Prize for literature in 2007. Her belief in the harmonious relationship between the man and the nature prevails in many of her works. In her new works, The Cleft Lessing raises a question and thinks once again about the relationship between males and females and between men and nature by retelling human beings' original history. She mainly focuses on people's attention on the relationships between literature and nature, women and nature, in order to arouse people's awareness of protecting nature and caring for women and the disadvantaged race from the perspective of the Ecofeminism. This paper analyses the links between women and nature in the novel and reveals males' ignorance and oppression to females and human beings' ignorance and oppression to nature both in the past and at the present time. It is concluded that only when the patriarchy no longer considers nature and women as "others" or "objects", could this world achieve equilibrium.
\end{abstract}

\section{Introduction}

Ecofeminism is the combinative product of environmental movement and the feminism of the modern era in the West. It was born in the end of 1970s-the start of 1980s among many of the social movements. The main representatives of Ecofeminism are Karen J. Warren, Val Pulpwood, Carolyn Merchant, Ariel Salleh, Vandana Shiva, Judith Plant, Rosemary R. Routher, Ynestra King and so on. These people gave many views and introduced social fairness into our eye reach from women special historical status. They made us not only think about the reasons of environment problems and ecological crises from new angle, but also turn on a new thought to settle these crises.

As counties forms of feminist and environmental theories and activism intersected, Ecofeminism or "ecological feminism" became a concept in the 1970s and 1980s. This term was first presented by Francoise d' Eaubonne in her book Le Feminisme ou la Mort published in 1974, who indicated that: There is direct link between the oppression on the women and nature, and attempted to call on the women to lead an ecology movement and reawake the relationship between men and women. Nowadays, whether in practical level or in the academic circles, the Ecofeminism has permeated through the philosophy, the religion, the literature, the economy and so on.

\section{The Links between the Women and the Nature in The Cleft}

Through the whole history of mankind nature is often feminized and women are often thought of to be closer to nature than men. Just like the women getting birth and taking care of the children, nature nurtures the universe. This is the close connection between woman and nature. Ecofeminists see this kind of connection clearly, and explore the relation between environmental degradation and gender oppression mostly as a cause of Western Patriarchal society. In Doris Lessing's The Cleft, the connection between nature and women is emerged from a new angle.

The Cleft is stated by a Roman senator in the last years of his life. There are two story lines in this novel. The first one is to retell the history of human creation and show people an ancient 
community of women-the clefts-who are little-known living in an Edenic coastal wilderness. And the other line is to tell the senator's life which occupies the smaller length of the article. The novelist Paul Auster gets the meaning of the length and put it simple: "In a work of fiction, one assumes there is a conscious mind behind the words on the pages.” (Auster, 1998:146)

In The Cleft Lessing shows the readers a new story about the creation of the human being, that is, the clefts-the ancient women-are the first kind of human, but not the men create the women with their ribs. The clefts live in the Cleft which is a mountain near the sea and led a peaceful and lazy life. They could survive in the nature and give birth to baby clefts with the help of moon. They bear female children when the moon gets full. One day, some "monsters" were born, which broke down the harmony of the sexless community. With the fear and shame, the clefts throw them away on the Killing Rock. "We didn't keep damaged babies, and we didn't keep twins...... When we put out deformed babies the eagles came for them. We did not kill the babes, the eagles did it." (Lessing, 2007:12) Even though, there were so many fewer in the caves, so many "monsters" had been born, more than the "clefts" . A long time later, the clefts found a monster on the part of seashore nearest to the Eagles' Hills. They didn't imagine that the "monsters" had started to build their own tribe on the other side of the island and rescued more baby "monsters". The clefts wanted to know the "monsters" life, and the "monsters" wanted to know the clefts as well. Then one day, the squirts captured a cleft and raped her by turns. Next, there were two clefts mated with the squirts. When they gave birth to children, they found they are different with the other babies. More and more the clefts and the squirts had sex, and more and more new babies were born. Not long later, the clefts can't pregnant without the squirts, which mean if they wanted to keep the population balance; they had to live with the squirts-the ancient males forever. At this time, some clefts led by Maire decided to live with the males. After fighting with the Old Shes, they lived together, and long time later the females had been used to living with the males, but the males didn't want to live the former peace and lazy life. They would like to change their own condition, and couldn't satisfy to live in this island. They would like to change their own condition, and couldn't satisfy to live in this island. They wanted to search another maybe larger and diner islands. So they decided to explore without a clear plan. Nevertheless, this expedition was not easy. Although they saw the island in the distance, it was hard to get there. They experienced many difficulties and some of them were killed by the mature. In the end, they went back to the former island. However, "He knew at once what had happened. There mend men, his brave young men had been unable to resist throwing a boulder or two down into the pit.” The males destroyed the females' homeland, however, the females had to accept the fact and forgive the males because of the love. Finally, they left the Cleft and got forward to find a new life.

During the ancient story, there is another line describing the recent life of the narrator, the Roman senator, who had a failing marriage with Julia and lived an embarrassing life with his two children, Lydia and Titus. When he was young, the senator married a girl he loved with his parents' improvement. And they got two boys soon. He wished to become a rich man all the time, so he works hard and finally became a senator. But his two sons were killed fighting against the German tribes. More unfortunately, his wife was past soon. He was overwhelmed and ill for a long time. Then a girl named Julia came to take care of him. Gradually he was in love with this girl who was poor but attractive and young. At last, they married with a deal that Julia must give birth to at least two children for him. But Julia's first delivery was difficult and suffering which made her afraid of it. Then the second one was another painful experience. So Julia didn't like her two children, even she didn't want to close to them. Lessing wants to show the importance of the harmony between men and nature by creating all kinds of human relations which all develop into no avail.

Ecofeminists claim: "female bodily experiences (e.g., of reproduction and childbearing), not female biology per se, situates women differently with respect to nature than men.” (Warren, 1993: 253-267) Caroly Merchant has suggested that witches stand for the part of nature which does not fit into the orderly pattern of the mathematical paradigm. "Disorderly women, like Chaotic nature, needed to be controlled." (Merchant, 1980: 127) The witches were seen as the rebels. In both Western literature and Estern literature, nature is always "feminized", while women are 
"naturalized". In the Chinese civilization, $\mathrm{Nv}$ Wa is said to be the first goddess who patched the sky. At first, she created the nature, such as sky, land, mountains, rivers, animals and all the living things except for the human. Then she used the soil to create her boys and girls according to her figure. For defending her children and the world she created, $\mathrm{Nv}$ Wa had to plug up the broken sky with her body at last. So in the mind of most Chinese people, Nv Wa is regarded as the mother of nature and the mother of earth all the time. In the Western, there is also a mother of earth, which is Gaia, who is the Western human beings' ausgangspunkt.

The links between nature and women also is revealed in our daily life. The earth, the ocean and the mountain are always called the mother by people. The lovely small animals are regarded as "she". Furthermore, the nature is always used to describe the women. For example, we can say: the girl is very beautiful like a flower; the women's eyes are clear as the lake; that girl has a gentle heart like water, and so on. The links exist everywhere and also obviously revealed in The Cleft. The following will analyze the links between nature and women from three aspects: symbol, experience and status.

Some ecofeminists think: men's aggression to the nature equals to male's invasion to female's body. In The Cleft, both nature and women experienced the men's aggression. Before they first gave birth to a baby boy, the clefts lived a very peaceful and happy life. But when they found the new baby have bump and hump and the thing like a pipe which is sometimes like a sea squirt they were frightened and didn't know how to deal with these “monsters”. They hadn't killed anybody, so they had to put them out for the eagles. The clefts considered that: "We did not kill the babes, the eagles did it.” (Lessing, 2007: 12) However, they didn't know why the eagles didn't kill the monsters but help them to survive. In this book, the eagles played the role of preserver of the males. When the clefts put the monsters on the Killing Rock, the eagles would carry them in their claws up to the hills where the nests are but instead of dropping the babies in a nest the eagles went on and carried them down into a valley where there were huts. When the eagles found the clefts want to kill the babies, they would let themselves down from the sky and took the babies in their claws and went off with them back in the direction of Eagles' Hills. For saving the males, the eagles developed a war with the first females. They "watched every move they made, and tried to wrest the monsters from them as they were born. Some of the females, the young ones attending to the monsters, were killed-swept into the sea and then kept from climbing out because the eagles hovered above them and pushed them under until they drowned. This war could not go on for long but it creates the females' first enemy. They hated the eagles, and for a time tried to hurt them by throwing stones, or beating at them with sticks. Not only fear, but elementary forms of attack and defense began in this sleepy (Maire word) community of the very first humans, the very first females.” (Lessing, 2007: 22) Therefore, the eagles became the first persecutor of the female antecedent to the male. Not only in this novel, but also in some stories the eagle is the symbol of the male and persecutes the female and the nature. They represent the power and influence.

We know we are in a society of Patriarchy, in which both women and nature's status are lower than men's. Most people believe that men's appeared is earlier than the women. In some stories of the origin of human's history, male is the creator of the female. For example, it is said the world was created by Pangu who was a man in the Chinese myth, and at the moment he left the world, his soul became the human being. In the Western, it is said that woman is created by the man using one of his rib. So Lessing tried to tell a different story about human being's origin in her The Cleft. At the beginning, she said: "In a recent scientific article it was remarked that the basic and primal human stock was probably female, and that males came along later, as a kind of cosmic afterthought. I cannot believe that this was a trouble-free advent. The idea was grist to an already active mill, for I had been wondering if men were not a younger type, a junior variation. They lack the solidity of women, who seem to have been endowed with a natural harmony with the ways of the world. I think most people would agree with this, even if a definition would be hard to come by. Men in comparison are unstable, and erratic.” (Lessing, 2007) However, in this kind of world, the woman's and nature's status is still unchanged. Whether who creates whom, it is not the reason to decide who are superior to the other one. However, it is still hard to make the nature, the female and the male on 
the equal status. In The Cleft, the author tells the people this status through the Roman senator's lips: "Immediately I confront a problem. I wrote there 'males and females', Males are always put first, in our practice. They are first in our society, despite the influence of certain great ladies of the noble Houses." The first scene in the novel tells us the woman is in the ignored status even if she wraps up with tough. Marcus and Lolla both were the senator's slaves, and they had known each other all their lives. Lolla was known for her quick temper. And not surprisingly that day, she rushed at Marcus screaming reproaches and accusations, though she used her eyes reproached and accused the boy again and again, he took no notice of her. He walked past her as if she were not there. Then she called him in her normal voice, but there was no answer. When she said again coaxingly, Marcus turned his head to look at her with contemptuous and anger. At last, she pleaded, seemed ready to cry, but only got the sight of Marcus's back. What Lolla had done was just for drawing Marcus's attention. Even if she was turned down she would never give up. She would try every means to be together with him. Here, the subjection of women is so clear. In our daily life, the story above is always on show in many different versions. A woman, maybe who is beautiful, who is smart, who is capable, who is a boss or in the important post, is always a housewife playing the role of a good wife and kind mother when she goes back home. In modern life, a woman should be omnipotent, she should work hard and try her best to get more money, and she should take care of the children, the husband and the whole family. Even though she does everything perfectly, she can't get men's even the other women's real improvement. The females are menial, meticulous and attached to the males, or they are not females, even not human being. Nowadays, people often say there are three kinds of men in the world: males, females and able women. In this sentence, we can see the able women are not regarded as the females. That's because the able women don't want to be subject to the men and threaten the men's power and status. In people's mind, female's subordinate status is deepseated. Even if the man makes a big mistake, woman should forgive him or undertake it or pretend not to see. Just like Lessing has said in The Cleft: "I have always found it entertaining that females are worshipped as goddesses, while in ordinary life they are kept secondary and thought inferior.” (Lessing, 2007: 27)

\section{Conclusion}

The Cleft, as Doris Lessing's masterpiece published in 2007, retells the history of human creation through an old contemplative Roman senator. The novel reveals us that although it was the female that creates the male and it was the nature that helps the male to survive in the novel, nature and women were still considered to be inferior to or lower than men. At the same time, it illustrates that the relationship between nature and women is closer than the relationship between nature and men. In the novel, Lessing shows not only the links between women and nature lie in the symbolic, the experiential and positional, but also the backgrounding and exclusion of women and nature in the world. When she produces this novel, Lessing's consciousness of Ecofeminism has been matured, so we can see her hope for human beings to establish a harmonious relationship between nature and human beings, men and women. In the end of the novel, Horsa and Maronna seemed to have found the fine world: “There, in Maronna's arms, loved and forgiven, somewhere in Horsa's restless mind had started the thought: Tell her about the wonderful place I found, yes I will. She'll want to see it too, I am sure of it. She will understand, yes, she'll come with me, we'll go together, I'll make a ship better than any we've made, and we'll land tighter on that shore and..." (Lessing, 2007: 258) If Horsas really realize the importance of the women and nature, and make good use of their dependence on each part, the beautiful world is not far away.

\section{References}

[1]. Attifield, Robin. (1983). The Ethics of Environmental Concern. Oxford: Blackwell.

[2]. Barry, Peter. (2002). Beginning Theory: An Introduction to Literary and Cultural Theory. Manchester Uuniversity Press. 
[3]. Benjamin, Jessica. (1988). The Bonds of Love: Psychoanalysis, Feminism and the Problem of Domination. London: Virago.

[4]. Bookchin, Murray. (1991). The Ecology of Freedom. New York: Black Rose Books.

[5]. Greene, Gayle. (1994). Doris Lessing: The Poetics of Change. Ann Arbour: U of Michigan Press.

[6]. Griffin, Susan. (1978). Woman and Nature. San Francisco: Harper and Row.

[7]. Klein, Carole. (2000). Doris Lessing: A Biography. London: Gerald Duckworth \& Co Ltd.

[8]. Lessing, Doris. (2007). The Cleft. New York: Harper Collins Publishers.

[9]. Mackinnon, Mary Heather, and Moni McIntyre, ed. (1995). Readings in Ecology and Feminist Theology. London: Sheed \& Ward. 